


\section{The Generation of 1914}

Robert Wohl

HARVARD UNIVERSITY PRESS

Cambridge, Massachusetts 
Copyright (C) 1979 by the President and Fellows of Harvard College

All rights reserved

Printed in the United States of America

Library of Congress Cataloging in Publication Data

Wohl, Robert.

The generation of 1914 .

Includes bibliographical references and index.

1. Europe-Intellectual life-20th century.

2. Youth-Europe-History. 3. Conflict of

generations. 4. European War, 1914-1918-Influence

and results. 5. Youth in literature. I. Title.

CB203.W63 909.82'1 78-21124

ISBN 0-674-34465-0

This book has been digitally reprinted. The content remains identical to that of previous printings. 
For Birgitta, who lived it 
